\title{
Professor Christopher Julian Hewitt FREng 1969-2019
}

It is with deep sadness that we announce the death of Professor Chris Hewitt FREng, an Executive Editor of Biotechnology Letters since 2007 and Editor in Chief since last year, who died in the early hours of 25 th July 2019, at the age of 50. He had suffered a short illness but his passing was very unexpected.

Chris graduated with a first class honours degree in Microbiology from Royal Holloway College, University of London in 1990 and then went to the University of Birmingham to read for a Ph.D. in Biochemical Engineering in the School of Chemical Engineering (1993). After a short break, mainly in industry, he returned to the School in 1996 as a post-doc at the end of which in 1999 he was appointed Lecturer, then Senior Lecturer in Biochemical Engineering. In 2006, he was appointed to a Chair in Biological Engineering at Loughborough University. Here he was co-founder of the EPSRC and MRC Centre for Doctoral Training in Regenerative Medicine and in 2011, he became Associate Dean for Research in the School of Aero, Auto, Chemical and Materials Engineering. He joined Aston University in November 2014 as Executive Dean of Life \& Health Sciences and Professor of Biological Engineering.

Chris was a leading biological engineer, distinguished for his research using flow cytometry and cell sorting to understand the interaction of the cell with the bioreactor environment within such diverse areas as microbial fermentation, bio-remediation, bio-transformation, brewing and cell culture. He was also the co-founder of the Centre for Biological Engineering at Loughborough University, where he developed a world-leading team in regenerative medicine bioprocessing. In particular, his team made a significant contribution to the literature on the culture and recovery of fully functional human mesenchymal stem cells in stirred bioreactors based on sound biochemical engineering and fluid dynamic considerations essential to scale-up for commercialisation.

In recognition of his achievements, he was awarded a DSc in Biochemical Engineering from Loughborough University (2013) and the Donald Medal by the Institution of Chemical Engineers for outstanding services to biochemical engineering (2017). In 2018, he was also elected Fellow of the Royal Academy of Engineering.

He will be sorely missed by colleagues and friends. Our thoughts are with his father, wife and two teenage sons.

Dr Ivan Wall,

Professor of Cell and Gene Therapy Bioprocessing, Aston University

Dr Alvin Nienow,

Emeritus Professor of Biochemical Engineering, University of Birmingham 
Visiting Professor of Biochemical Engineering, Loughborough University

Visiting Professor, Aston University
Publisher's Note Springer Nature remains neutral with regard to jurisdictional claims in published maps and institutional affiliations. 